\title{
DIEL VARIATIONS IN DENSITY AND DIVERSITY OF MICRO-PHYTOPLANKTON COMMUNITY IN AND AROUND A BARACHOIS-BASED OYSTER CULTURE FARM
}

\author{
SOONDUR MOUNESHWAR*1, KAULLYSING DEEPEEKA ${ }^{1}$, BOOJHAWON RAVINDRA ${ }^{2}$, \\ LOWE RYAN ${ }^{3}$, CASARETO BEATRIZ ESTELA ${ }^{4}$, SUZUKI YOSHIMI ${ }^{4}$ AND BHAGOOLI \\ RANJEET ${ }^{1,5,6}$
}

${ }^{1}$ Department of Biosciences and Ocean Studies, Faculty of Science \& Pole of Research Excellence in Sustainable Marine Biodiversity, University of Mauritius, Réduit 80837, Republic of Mauritius. ${ }^{2}$ Department of Mathematics, Faculty of Science, University of Mauritius, Réduit 80837, Republic of Mauritius. ${ }^{3}$ School of Earth and Environment and UWA Oceans Institute, University of Western Australia, M004 - 35 Stirling Highway, Crawley WA 6009, Australia. ${ }^{4}$ Graduate School of Science and Technology, Shizuoka University, Japan. Institute of Oceanography and Environment (INOS), University Malaysia Terengganu, 21030 Kuala Nerus, Terengganu, Malaysia. ${ }^{6}$ The Biodiversity and Environment Institute, Réduit, Republic of Mauritius.

*Corresponding author: mouneshwar.soondur@gmail.com

Submitted: 12 September 2019 Accepted: 20 January 2020

http://doi.org/10.46754/jssm.2020.06.002

\begin{abstract}
Knowledge of diel variations in phytoplankton communities is important to set up and plan a successful and sustainable bivalve aquaculture industry. This study investigated the diel (24-hour cycle) variations in micro-phytoplankton community during two high and two low tides over two alternate days in summer at a barachois-based oyster farm in Mauritius, a micro-tidal tropical island. Micro-phytoplankton density and diversity, sea surface chlorophyll $a$ concentration, and physico-chemical parameters, such as sea surface temperature, dissolved oxygen, $\mathrm{pH}$ and salinity, were assessed each day during high and low tides, at an interval of approximately six hours at 11 stations. Despite the small tidal range, significant diel variations in micro-phytoplankton density were noted throughout the tidal cycle. Highest densities of micro-phytoplankton and diversity of diatoms, dinoflagellates and cyanobacteria were recorded at stations three and six ( $\mathrm{S} 3$ and S6). The range of total micro-phytoplankton at $\mathrm{S} 3$ and $\mathrm{S} 6$ varied above $2.0 \times 10^{5}$ cells $\mathrm{L}^{-1}$ and for the other stations, it varied mainly between 1 to $2 \times 10^{5}$ cells $\mathrm{L}^{-1}$ throughout all the tides, except on the second sampling day, where at $\mathrm{S} 1$ and $\mathrm{S} 7$, the density was slightly above $2 \times 10^{5}$ cells L ${ }^{-1}$. The diatom Coscinodiscus (14\%), the dinoflagellates Peridinium (18\%) and the cyanobacteria Anabaena (24\%) were dominant. S3 and S6 within the barachois having a low flushing rate were characterized by the highest availability of food stock, inferring that these stations may sustain an optimal growth of bivalves. These findings may be useful in directing the barachois-based bivalve culture site towards a more effective and sustainable management by locating the most appropriate culture areas in the system.
\end{abstract}

Keywords: Barachois, chlorophyll $a$, diel variation, micro-phytoplankton, oyster culture farm.

\section{Introduction}

Coastal ecosystems are diverse regions that encompass a wide array of social, economic, and environmental resources (Coleman \& Williams, 2002). However, if action is not taken at the opportune time, the overexploitation of these resources can lead to habitat degradation, pollution, and modification of ecosystem functions (Lauck et al., 1998). Worldwide, it has been noted that fish abundance is declining and thus, to overcome the collapsing fisheries sector, big companies and small entrepreneurs are turning towards aquaculture to farm fish, oysters, mussels, and other shellfish. However, when establishing aquaculture sites in coastal zones, it should be noted that complex interactions with other coastal services will occur and hence, one should know how to optimize the farm in ensuring good carrying capacity while maintaining the ecosystem's health (Browman \& Stergiou, 2004). 
Typically, oyster farms are dependent on several parameters, such as availability of microphytoplankton species like as Chaetoceros and Thalassiosira (Hashimoto et al., 2008; McCausland et al., 1999), optimum sea surface temperature, level of chlorophyll $a$, dissolved oxygen (DO) and a suitable salinity regime (Brown \& Hartwick,1988; Gagnaire et al., 2006). The main food sources for oysters, which are filter feeders, are microscopic phytoplankton. To sustain an oyster farm, there should be an adequate supply of phytoplankton coupled with optimal water temperature (Bernard et al., 2011). A drastic change in temperature has been proven disastrous for these shellfish, whereby an increase result in high mortality rates (de Kantzow et al., 2016).

Furthermore, when there is fresh water discharge into the seawater of a shellfish farm, this leads to changes in the salinity gradient and thus, impacts marine life. Moreover, many studies have shown that some microphytoplankton are toxic when present in high densities (blooming). The filter feeders that feed on these phytoplankton may become toxic, causing fatalities when they, in turn, are consumed by those on top of the food chain, i.e. humans (Jiang et al., 2017). Phytoplankton blooms generally occur when there is a density of around $10^{7}-10^{8}$ cells/L (Carstensen et al., 2015). Among the toxic phytoplankton are the diatom Nitzschia, which contains domoic acid (Bates et al., 1991), the dinoflagellates Gonyaulax and Dinophysis (Tangen, 1983), and dinoflagellate Alexandrium, which produces the spirolide shellfish toxin (Cembella et al., 2000). Hence, it is of prime importance to determine the species of phytoplankton present in aquaculture farms to monitor the presence of toxic genera.

Assessment of variations in phytoplankton during the whole diel (24-hour) cycle is needed to thoroughly understand their dynamics in terms of density and diversity, their implications on coastal waters, optimization of operations, and productivity of the oyster farm. During a diel cycle, we have two alternating low and high tides (four tide levels), and during each tide, there is exchange of water in and out of different ecosystems, whereby several parameters like oxygen level and nutrient concentration, are replenished, (Gianesella et al., 2000). Tidal change also brings about stabilization in the salinity and $\mathrm{pH}$ of the seawater. An in-depth study on the phytoplankton community throughout a 24-hour period will provide an insight on the carrying capacity of the ecosystem in terms of food availability (Jiang \& Gibbs, 2005). It is of prime importance to know the food availability, especially in an aquaculture system, to ensure optimal growth of cultured bivalves and other marine organisms.

Around Mauritius Island, several studies have been carried out to determine changes in different physico-chemical parameters (Turner et al., 2002 Bhagooli; Taleb-Hossenkhan, 2012; Bhagooli \& Kaullysing, 2019) and some studies have focused on their association with phytoplankton (Bhagooli \& Hidaka, 2004; Sadally et al., 2014a; Sadally et al., 2014b; Sadally et al., 2015). It is also predicted that the marine environment is going to become warmer within a short period of time (Bhagooli \& Sheppard, 2012). Limited study on the variation of phytoplankton across a fish aquaculture system has been conducted (Sadally et al., 2015). Recently, a study in the northeast of Mauritius Island has provided the baseline data over a few months on micro-phytoplankton communities at a barachois-based oyster farm (Armance et al., 2019). However, details are limited on complete cycles of phytoplankton variation during a whole diel period focusing on each tidal change, and the effects they cause on a semi-enclosed barachois culture system are not known. The barachois, as such, is an enclosed coastal lagoon with limited water exchange from the ocean, which increases the residence time of the water inside. Thus, this study investigated the diel variations in density and diversity of the microphytoplankton community in a barachois oyster farm, and the factors affecting their growth. Furthermore, physico-chemical parameters, such as temperature, salinity, $\mathrm{pH}$ and $\mathrm{DO}$, were recorded at different tides over two alternate days. 


\section{Material and methods}

\section{Study Site}

The oyster culture site at Poudre d'Or is approximately $0.04 \mathrm{~km}^{2}$ and is situated in the northeast coast of Mauritius (Figure 1A). Figure 1B shows the different stations within and outside the barachois. Stations one to seven (S1-7) were inside the barachois and stations eight to 11 were (S8-11) outside. These different stations were selected based on different water ecosystems, depths, flow directions, flow rates and transparency (Table 1).
At this region of Mauritius, there was higher tidal change, which was over $40 \mathrm{~cm}$ on average, especially inside the barachois, whereby the oysters were exposed to sunlight during low tides. This was very beneficial for the oysters as sunlight would ensure proper growth and decrease their mortality rate. The barachois water was influenced by different environmental factors, owing to the presence of river discharge and other ecosystem like small mangrove patches. Furthermore, Poudre d'Or is a highly populated region and hence, in some ways, there could be anthropogenic activities

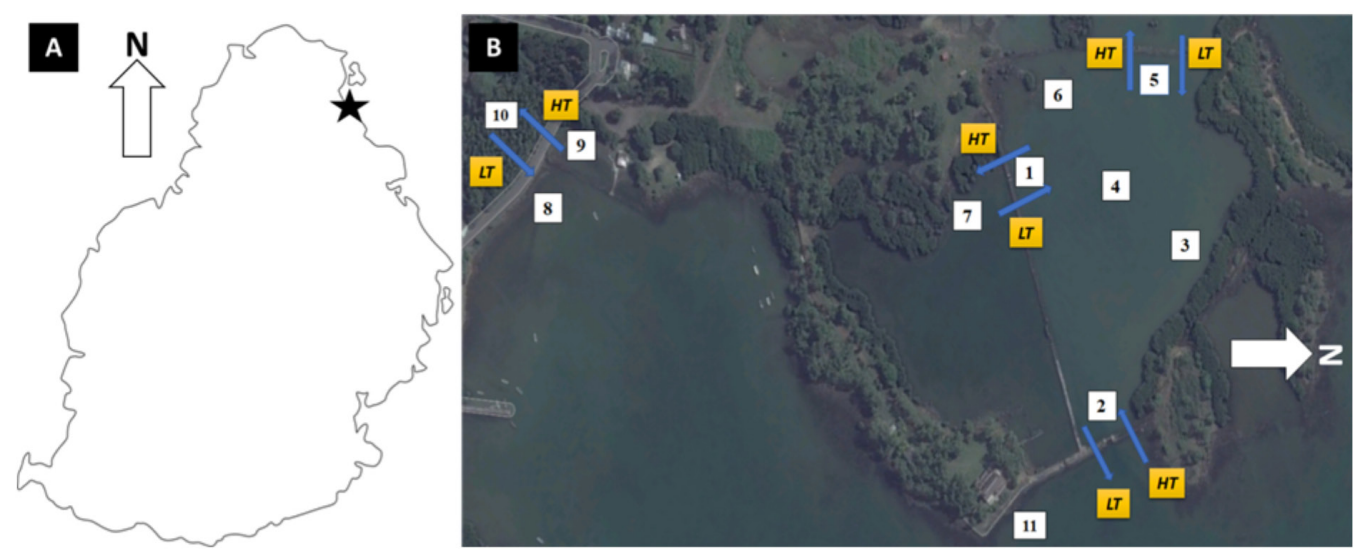

Figure 1: The map of Mauritius Island located within the latitude $20^{\circ} 17 \mathrm{~S}$ and longitude $57^{\circ} 33 \mathrm{E}$, where the star symbol marks the study site at Poudre d'Or; B: The site at Poudre d'Or with stations one to seven inside the farm and stations eight to 11 outside. North is denoted by the symbol "N"

Table 1: The stations at the aquaculture farm at Poudre d'Or with their respective water depths, ecosystem differences, water flow rates and water transparency

\begin{tabular}{lcllc}
\hline Station & $\begin{array}{c}\text { Water } \\
\text { Depth }\end{array}$ & \multicolumn{1}{c}{ Ecosystem/Water flow direction } & $\begin{array}{c}\text { Water flow } \\
\text { rate }\end{array}$ & $\begin{array}{c}\text { Water } \\
\text { Transparency }\end{array}$ \\
\hline 1 & $0.8-1.0 \mathrm{~m}$ & Exchange point of mangrove water in/out of farm & Turbulent & $<0.5 \mathrm{~m}$ \\
2 & $1.8-2.0 \mathrm{~m}$ & Adjacent seawater outside barachois moving in and out & Well-flushed & $<0.5 \mathrm{~m}$ \\
3 & $0.3-0.5 \mathrm{~m}$ & Near the mangrove & Calm & $<0.2 \mathrm{~m}$ \\
4 & $1.8-2.0 \mathrm{~m}$ & High depth with high water flow & Turbulent & $<0.5 \mathrm{~m}$ \\
5 & $0.8-1.0 \mathrm{~m}$ & Water flow in and out continuously & Turbulent & $<0.5 \mathrm{~m}$ \\
6 & $0.3-0.5 \mathrm{~m}$ & Oyster and crab aquaculture site & Calm & $<0.2 \mathrm{~m}$ \\
7 & $0.3-0.5 \mathrm{~m}$ & Near the mangrove & Calm & $<0.2 \mathrm{~m}$ \\
8 & $0.8-1.0 \mathrm{~m}$ & Mixing of river and seawater & Turbulent & $<0.5 \mathrm{~m}$ \\
9 & $0.3-0.5 \mathrm{~m}$ & The river estuary meeting the sea & Turbulent & $<0.2 \mathrm{~m}$ \\
10 & $1.8-2.0 \mathrm{~m}$ & Riverbed of fresh water in/out into sea & Turbulent & $<1.0 \mathrm{~m}$ \\
11 & $0.8-1.0 \mathrm{~m}$ & Well mixed coastal seawater & Well-flushed & $<0.5 \mathrm{~m}$ \\
\hline
\end{tabular}


that degraded the quality of water in that area. The diel variation of micro-phytoplankton was investigated, and samples were taken at the 11 stations in triplicates at an interval of six hours for two alternate days (March 31 and April 2, 2018). The sampling was conducted in such a way that it included different tides (two high tides (HT) and two low tides (LT)) in 24hour cycles (Table 2). The first sampling was conducted on March 31, 2018, and it was during a spring tide, whereby the tidal change was the highest. The second sampling was done on April 2, 2018, which was one day after the spring tide.

\section{Sample Collection and Processing}

\section{Micro-phytoplankton}

Samples were collected in triplicates at each station on each sampling day. For microphytoplankton samples, $10 \mathrm{~L}$ of seawater were filtered through a $5 \mu \mathrm{m}$ plankton mesh. Eventually the residue was collected and centrifuged at $3500 \mathrm{rpm}$ for 10 minutes (Sadally et al., 2014a) to concentrate the microphytoplankton, followed by counting on a Sedgwick Rafter counting chamber (Devassy \& Goes, 1991) placed under a microscope to determine diversity and abundance (Tomas, 1996). The density of micro-phytoplankton was calculated as cells $\mathrm{L}^{-1}$. The cyanobacteria were mainly filamentous, and, on average, there were 15 cells in each filament.

\section{Chlorophyll a}

Chlorophyll a samples were collected in triplicates at each station on each day. A total of $500 \mathrm{ml}$ of seawater was collected and filtered through a $0.45 \mu \mathrm{m}$ pore size Whatman glass fibre filter paper. The filter paper was placed in a tube wrapped in aluminum foil, followed by the addition of $10 \mathrm{ml}$ of $90 \%$ acetone for the extraction of chlorophyll $a$ pigments and stored at $4{ }^{\circ} \mathrm{C}$ in the dark. The absorbance was read using a UV spectrophotometer at wavelengths of $630,647,664$ and $750 \mathrm{~nm}$ after 24 hours to determine chlorophyll $a$ concentration (Jeffrey \& Humphrey, 1975).

\section{Physico-chemical Parameters}

The Hanna HI 9142 dissolved oxygen meter (Hanna Instruments, Woonsocket, RI, USA) was used to measure the DO level at the surface of the seawater. For salinity, a refractometer (ERMA) was used. Water temperature and $\mathrm{pH}$ at stations were measured using a thermometer and $\mathrm{pH}$ meter, respectively.

\section{Statistical analysis}

Data analysis was carried out using the PASW Statistics 18, SPSS software. Two-way ANOVA, Pearson's Correlation and Tukey's HSD posthoc tests were performed. Model assumption for normality was verified and non-normally distributed data was transformed using the $\log _{10}$ or Arcsine transformation. Shannon-Wiener, Equitability and Evenness diversity indices were used to determine the variability of the different micro-phytoplankton genera. Statistical tests were considered significant at $\alpha=5 \%$ level.

Table 2: The two sampling days with the tidal range and tidal time change

\begin{tabular}{|c|c|c|c|c|c|c|c|c|}
\hline \multirow[b]{2}{*}{ Date } & \multicolumn{2}{|c|}{ 1st High Tide } & \multicolumn{2}{|c|}{ 1st Low Tide } & \multicolumn{2}{|c|}{ 2nd High Tide } & \multicolumn{2}{|c|}{ 2nd Low Tide } \\
\hline & Time & Height & Time & Height & Time & Height & Time & Height \\
\hline \multirow{2}{*}{$31 / 03 / 2018$} & 01:13 a.m & $86 \mathrm{~cm}$ & 07:31 a.m & $29 \mathrm{~cm}$ & 13.10 p.m & 86 & 19:36 p.m & $27 \mathrm{~cm}$ \\
\hline & \multicolumn{4}{|c|}{ Tidal Range $=57 \mathrm{~cm}$} & \multicolumn{4}{|c|}{ Tidal Range $=59 \mathrm{~cm}$} \\
\hline \multirow{2}{*}{$02 / 04 / 2018$} & 02.00 a.m & $83 \mathrm{~cm}$ & 08.33 a.m & $29 \mathrm{~cm}$ & 14.18 p.m & $82 \mathrm{~cm}$ & $20.30 \mathrm{pm}$ & $35 \mathrm{~cm}$ \\
\hline & \multicolumn{4}{|c|}{ Tidal Range $=54 \mathrm{~cm}$} & \multicolumn{4}{|c|}{ Tidal Range $=47 \mathrm{~cm}$} \\
\hline
\end{tabular}




\section{Results}

\section{Micro-phytoplankton Density}

The Total Phytoplankton Density (TPD) was highest at S3 and S6, and this trend was followed by diatoms, dinoflagellates, and cyanobacteria (Figure 2). Two-way ANOVA showed that there was significant diel variation, i.e., difference on average, for the TPD during the study period. Significant diel variation was also noted for
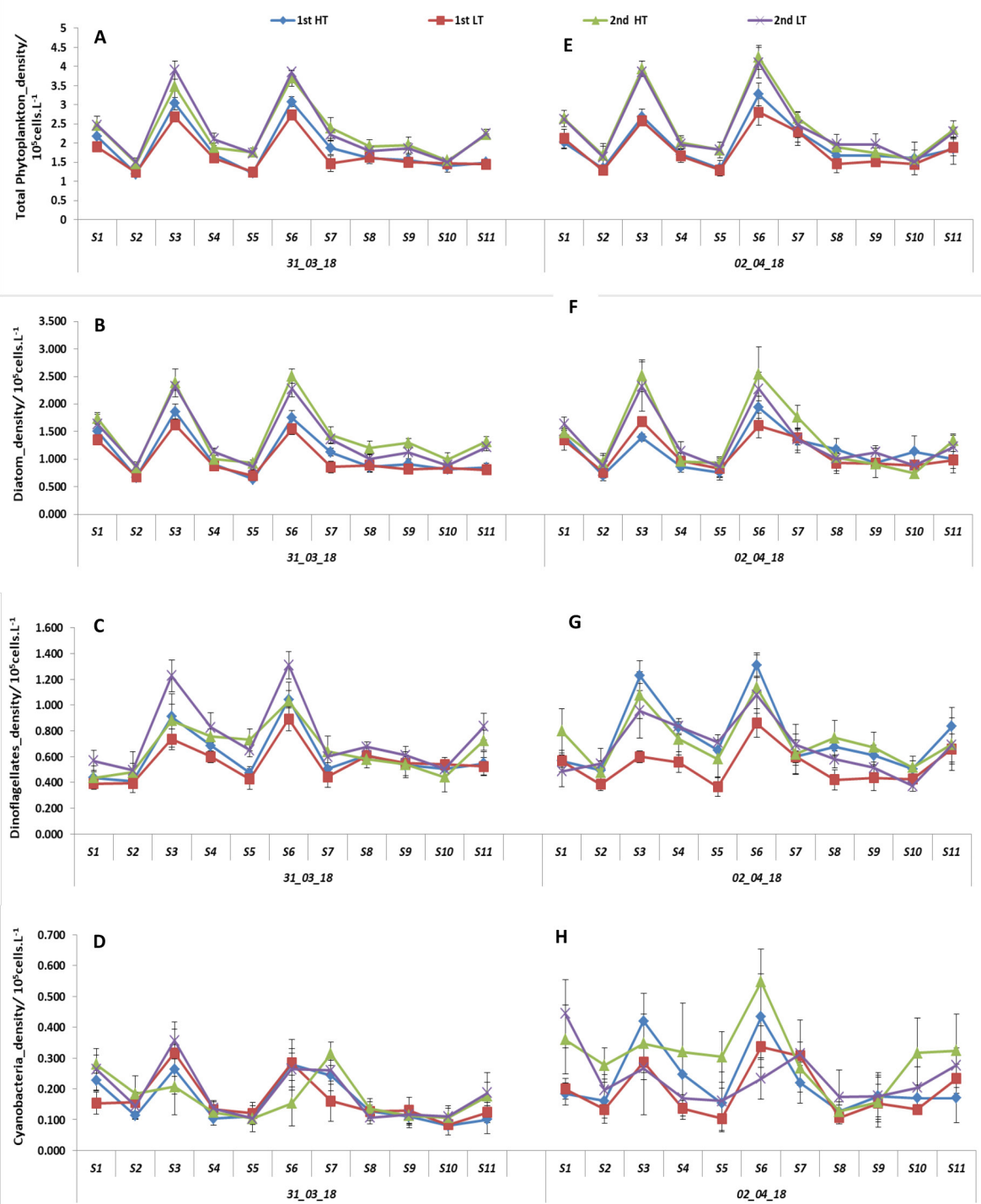

Figure 2: A, B, C and D represent the densities of total phytoplankton, diatoms, dinoflagellates and cyanobacteria, respectively, on March 31, 2018, at four different tides; E, F, G and H represent the densities of total phytoplankton, diatoms, dinoflagellates and cyanobacteria, respectively, on April 2, 2018, at four

different tides, where HT= High tide and $\mathrm{LT}=$ Low tide. Bars represent standard deviation $(\mathrm{n}=3)$ 
diatoms and dinoflagellates. For cyanobacteria, the combined difference was not significant.

The $2^{\text {nd }}$ HT and $2^{\text {nd }}$ LT had higher density of total micro-phytoplankton compared to the $1^{\text {st }}$ HT and $1^{\text {st }}$ LT (Figure 2). Tukey's HSD post-hoc test was performed to compare the mean densities of diatoms, dinoflagellates, cyanobacteria, and phytoplankton at different tides. On average, there were strong significant differences ( $p$ $<0.001)$ in TPD under mostly all four tidal pairwise comparisons $\left(1^{\text {st }} \mathrm{HT}, 1^{\text {st }} \mathrm{LT}, 2^{\text {nd }} \mathrm{HT}\right.$ and $2^{\text {nd }}$ LT), except for just a significant and nonsignificant difference between the pairs $1^{\text {st }} \mathrm{HT} / 1^{\text {st }}$ LT $(p<0.05)$ and $2^{\text {nd }} \mathrm{HT} / 2^{\text {nd }} \mathrm{LT}$, respectively. Similarly, for diatom and dinoflagellates densities, all pairwise differences were strongly significant except for the comparisons between $1^{\text {st }} \mathrm{HT} / 1^{1^{\text {st }}} \mathrm{LT}$ and $2^{\text {nd }} \mathrm{HT} / 2^{\text {nd }} \mathrm{LT}$. Furthermore, for cyanobacteria density, significant differences existed only between $1^{\text {st }} \mathrm{HT} / 2^{\text {nd }} \mathrm{HT}$ and $1^{\text {st }} \mathrm{LT} / 2^{\text {nd }}$ HT (Table 4).

Table 3: Two-way ANOVA comparing the densities of diatoms, dinoflagellates, cyanobacteria and total phytoplankton at different tides and stations

\begin{tabular}{lllllll}
\hline TDP & $\boldsymbol{S S}$ & $\boldsymbol{d f}$ & $\boldsymbol{M S}$ & $\boldsymbol{F}$ & $\boldsymbol{p}$-value \\
\hline & & & & & & \\
& Tides & 0.669 & 3 & 0.223 & 104.639 & $* * *$ \\
& Stations & 3.990 & 10 & 0.399 & 187.340 & $* * *$ \\
& Tides * Stations & 0.106 & 30 & 0.004 & 1.665 & $*$ \\
\hline Diatom & & & & & \\
& Tides & 0.668 & 3 & 0.223 & 59.956 & $* * *$ \\
& Stations & 5.176 & 10 & 0.518 & 139.318 & $* * *$ \\
& Tides * Stations & 0.222 & 30 & 0.007 & 1.989 & $* *$ \\
\hline & & & & & \\
& Tides & 0.588 & 3 & 0.196 & 27.779 & $* * *$ \\
& Stations & 3.041 & 10 & 0.304 & 43.069 & $* * *$ \\
& Tides * Stations & 0.318 & 30 & 0.011 & 1.499 & $*$ \\
\hline & & & & & \\
& Tides & 0.496 & 3 & 0.165 & 5.698 & $* * *$ \\
& Stations & 5.112 & 10 & 0.511 & 17.623 & $* * *$ \\
& Tides * Stations & 0.947 & 30 & 0.032 & 1.088 & NS \\
\hline
\end{tabular}

$\mathrm{p}<0.001=* * *, \mathrm{p}<0.01=* *, \mathrm{p}<0.05=*, \mathrm{NS}=$ Not Significant.

Table 4: Tukey's HSD post-hoc test for comparing means of the densities of diatoms, dinoflagellates, cyanobacteria, and total phytoplankton at different tides

\begin{tabular}{|c|c|c|c|c|c|}
\hline & & $\begin{array}{l}\text { Diatom } \\
\text { p-value }\end{array}$ & $\begin{array}{c}\text { Dinoflagellates } \\
\text { p-value }\end{array}$ & $\begin{array}{c}\text { Cyanobacteria } \\
\text { p-value }\end{array}$ & $\begin{array}{c}\text { TPD } \\
\text { p-value }\end{array}$ \\
\hline \multirow{3}{*}{ 1st_High Tide } & 1st_Low Tide & NS & NS & $\mathrm{NS}$ & $*$ \\
\hline & 2nd_High Tide & $* * *$ & $* * *$ & $* *$ & $* * *$ \\
\hline & 2nd_Low Tide & $* * *$ & $* * *$ & NS & $* * *$ \\
\hline \multirow{2}{*}{ 1st_Low Tide } & 2nd_High Tide & $* * *$ & $* * *$ & $* * *$ & $* * *$ \\
\hline & 2nd_Low Tide & $* * *$ & $* * *$ & NS & $* * *$ \\
\hline 2nd_High Tide & 2nd_Low Tide & NS & NS & NS & NS \\
\hline
\end{tabular}

Journal of Sustainability Science and Management Volume 15 Number 4, June 2020: 2-17 


\section{Diversity of Micro-phytoplankton Genera}

The highest densities of phytoplankton were recorded at $\mathrm{S} 3$ and $\mathrm{S} 6$ and hence, a more detailed investigation was carried out for these stations as they could be the best zones for aquaculture because of abundant food source. The percentage of different micro-phytoplankton genera was calculated based on S3 and S6, and the figure was averaged for the four tides and for both sampling days. Diatoms were observed to be dominant, followed by dinoflagellates and cyanobacteria. For diatom groups, the percentage contribution mostly varied around $2 \%$ except for the genera Chaetoceros, Coscinodiscus, Fragillaria,
Licmorphora, Navicula and Nitzschia. In the top six dominant diatoms, the percentage contribution was highest at S6 compared to S3 for Coscinodiscus, Fragillaria, Licmorphora, Navicula and Nitzschia, except Chaetoceros, where S3 had higher percentage contribution. For dinoflagellates, Ceratium and Peridinium were the most abundant. For both these dinoflagellates, the percentage were higher at S6 compared to S3. Among the seven cyanobacteria genera, the Anabaena, Lyngbya, Nodularia and Oscillatoria were the most dominant, followed closely by Phormidium, Snowella and Spirulina (Figure 3).
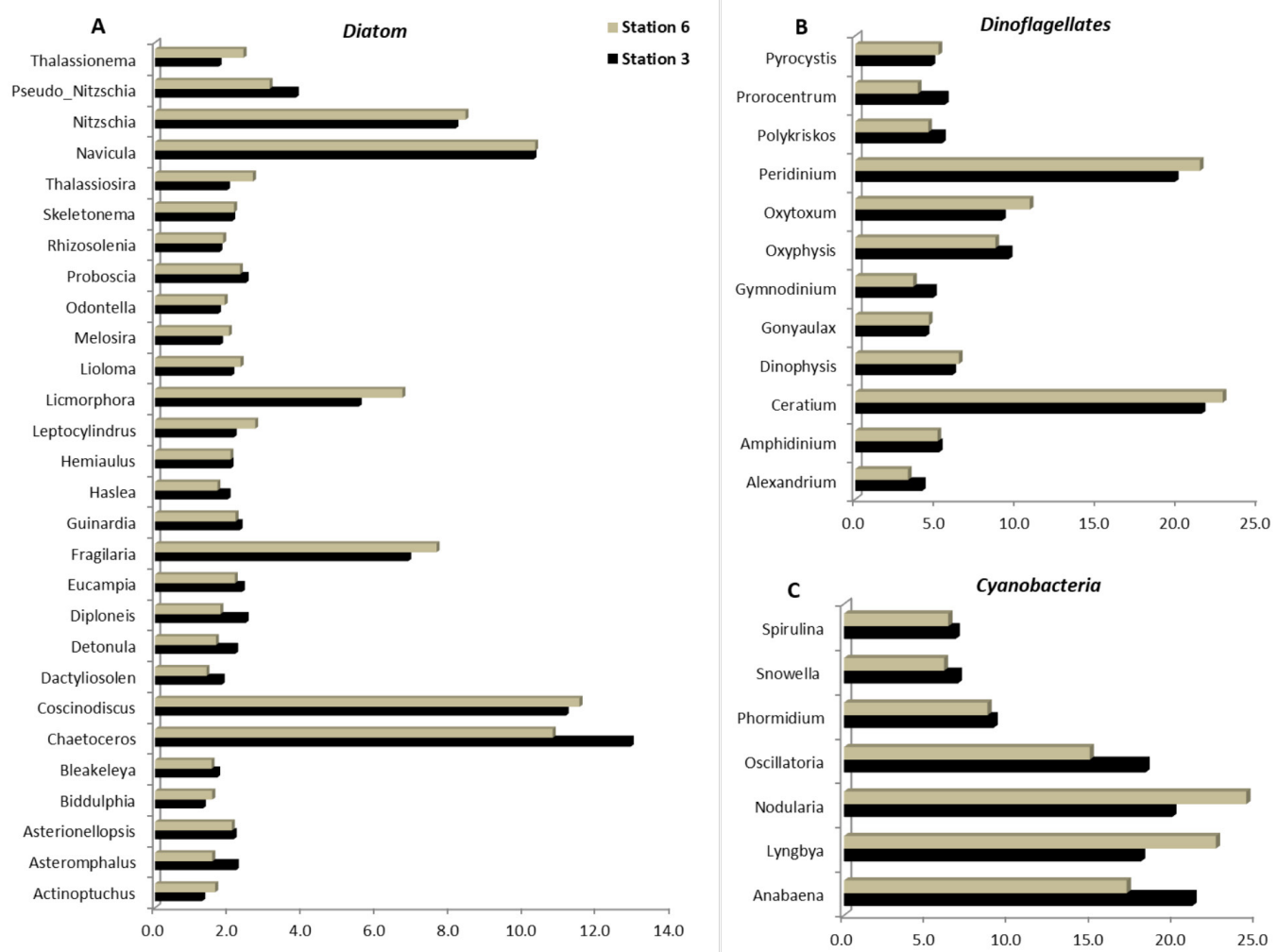

Figure 3: Percentage of different micro-phytoplankton genera calculated separately for the three groups of microphytoplankton, namely diatoms, dinoflagellates and cyanobacteria, accounting for $100 \%$ each at stations 3 and 6 on average for two sampling days (31/03/18 and 02/04/18): A: Percentage of different diatom genera (100\% total); B: Percentage of dinoflagellates (100\% total); C: Percentage of cyanobacteria (100\% total) 
Stations 3 and 6 were chosen to perform different diversity indices (Shannon-Wiener, Equitability and Evenness) for both sampling days. S6 was the area where oysters were cultured. During this study, both stations had the highest TPD, hence they were chosen to perform the indices to see whether they resembled each other in terms of genera variation during the two 24-hour cycles. The highest values for Shannon-Wiener, Equitability and Evenness for 28 different genera of diatoms were recorded at the $1^{\text {st }} \mathrm{HT}$ for both stations and on both sampling days. The trends for the different indices for both days resembled each other (Figure 4).

\section{Physico-chemical parameter and Chlorophyll a Concentration}

Two-way ANOVA revealed that there were strong significant differences on average $(p<$ 0.001 ) for $\mathrm{pH}$, temperature, and chlorophyll $a$ concentration at different tides, except for salinity and DO, which were not significantly different. Furthermore, it was found that there were strong significant differences $(p$
$<0.001$ ) for $\mathrm{pH}$, salinity, DO, temperature, and chlorophyll $a$ concentration station-wise. Higher $\mathrm{pH}$ and DO were recorded on April 2, 2018, compared to March 31, 2018, when all four tidal changes occurred, and salinity was inversed. Temperature was higher on April 2, 2018 , except during the $2^{\text {nd }}$ LT and tide-wise, the highest temperature was recorded during the $2^{\text {nd }}$ HT on both days. Higher chlorophyll $a$ concentration was recorded on April 2, 2018, except during the $1^{\text {st }}$ HT. Moreover, the $1^{\text {st }}$ HT had resulted in the lowest chlorophyll $a$ concentration on both days.

The Tukey's HSD post-hoc test showed that there were strong significant differences $(p<$ $0.001)$ during all the tides for $\mathrm{pH}$ and chlorophyll $a$ concentration. It was fairly the same case for temperature; except for $1^{\text {st }} \mathrm{LT} / 2^{\text {nd }} \mathrm{LT}$, where the difference was not significant. For salinity and DO, there were no significant differences irrespective of tide. Pearson correlations between the densities of diatoms, dinoflagellates, cyanobacteria and total phytoplankton with chlorophyll $a, \mathrm{pH}$, salinity, DO and temperature
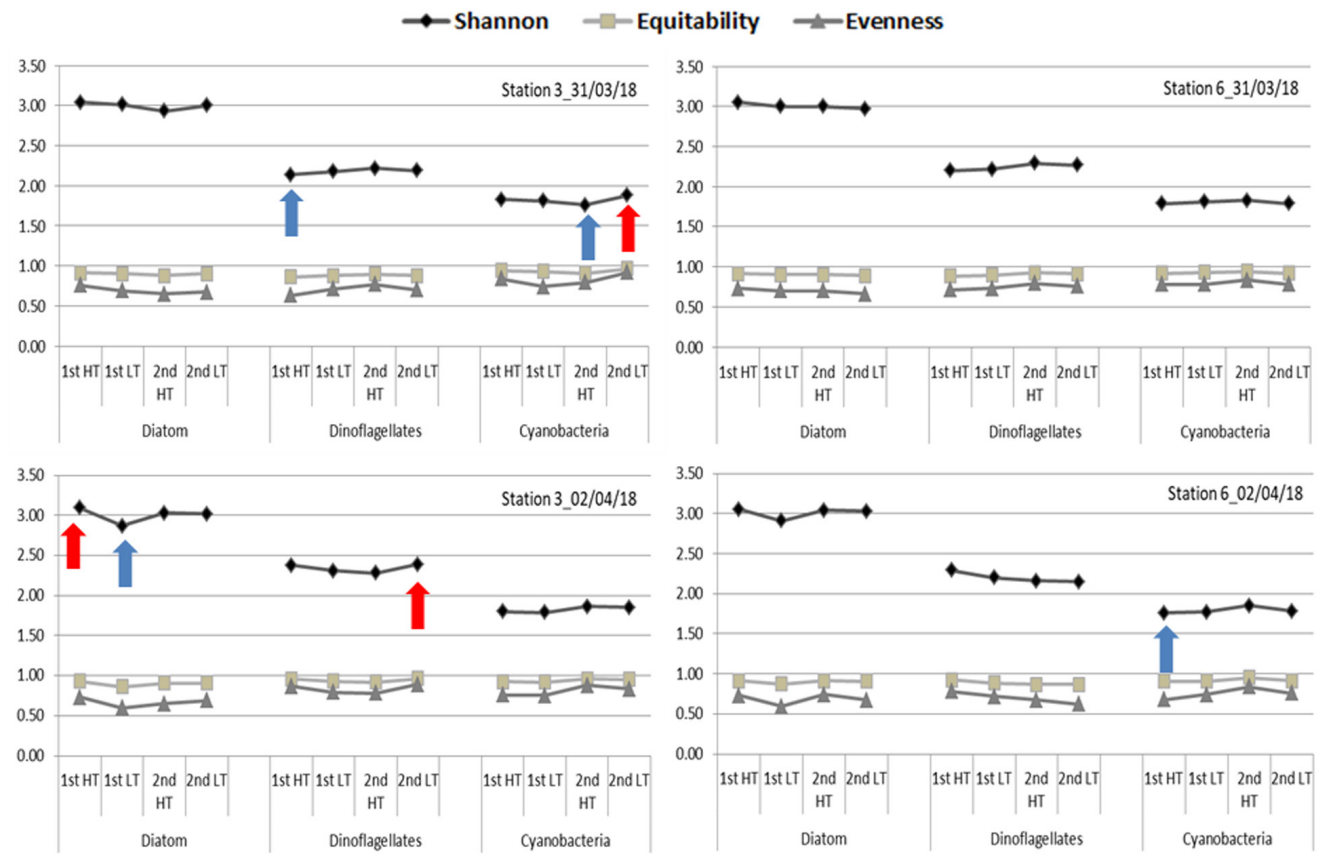

Figure 4: Shannon-Wiener diversity index, Equitability and Evenness of the different genera of diatoms, dinoflagellates and cyanobacteria at stations 3 and 6. Red arrow: highest values; Blue arrow: lowest values 
were positive. Strongly positive correlations $(p<$ 0.01 ) were noted between salinity and DO with all micro-phytoplankton densities. But there was no significant correlation between cyanobacteria density and chlorophyll $a$ compared to other micro-phytoplankton densities. No significant correlation between diatom and dinoflagellate densities were observed with $\mathrm{pH}$.

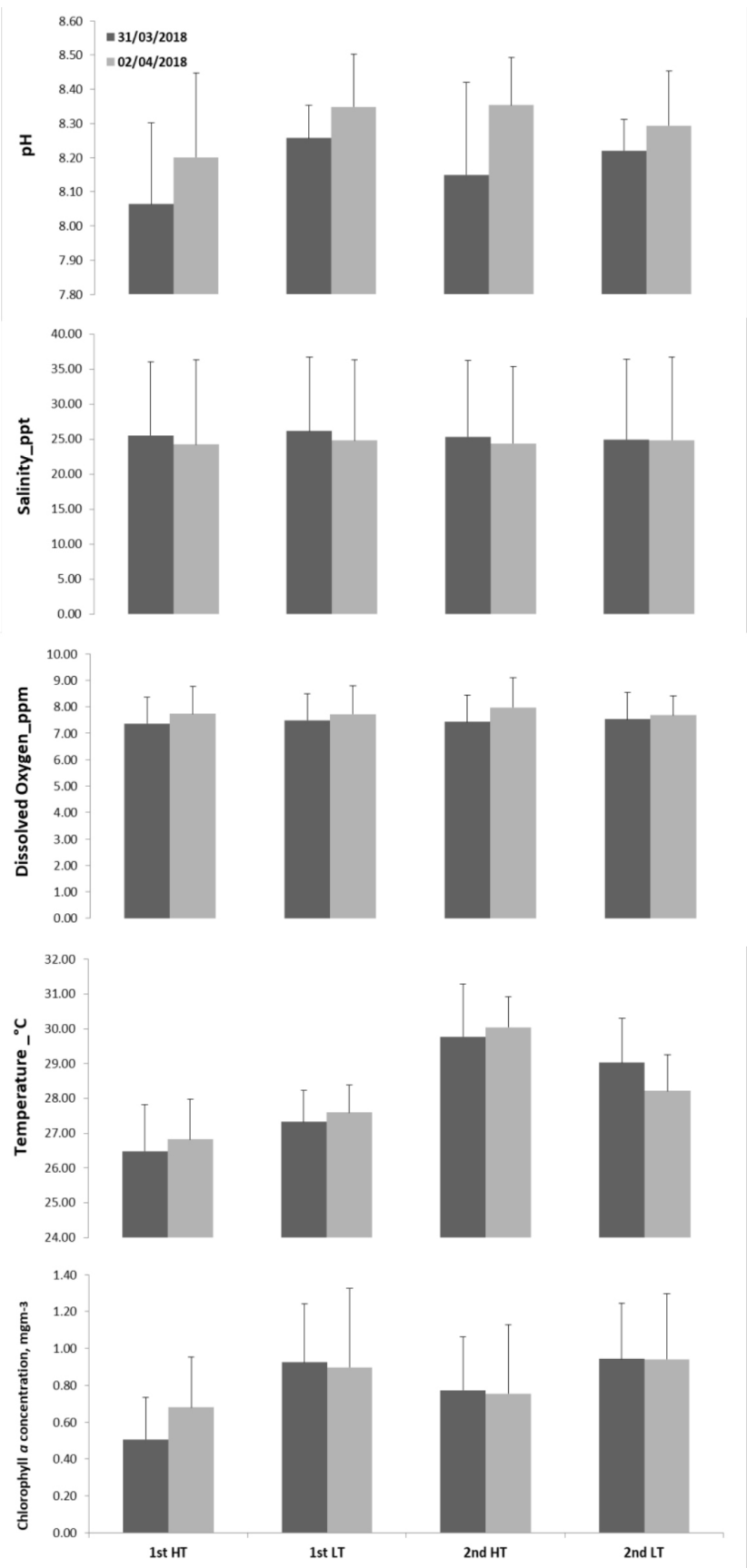

Figure 5: Physico-chemical parameters and chlorophyll $a$ variation during each tide for the two sampling days (March 31 \& April 2, 2018). HT: High tide and LT: Low tide. Bars represent standard deviation $(\mathrm{n}=3)$ 
Table 5: Two-way ANOVA for comparing pH, salinity, dissolved oxygen, temperature and chlorophyll $a$ concentration at different tides and station

\begin{tabular}{|c|c|c|c|c|c|c|}
\hline Parameters & Effect & $S S$ & $d f$ & $M S$ & $F$ & p-value \\
\hline \multicolumn{7}{|l|}{$p H$} \\
\hline & Tides & 0.003 & 3 & 0.001 & 12.810 & $* * *$ \\
\hline & Stations & 0.007 & 10 & 0.001 & 8.841 & $* * *$ \\
\hline & Tides $*$ Stations & 0.008 & 30 & 0.001 & 3.458 & $* * *$ \\
\hline \multicolumn{7}{|l|}{ Salinity } \\
\hline & Tides & 0.028 & 3 & 0.009 & 1.254 & NS \\
\hline & Stations & 40.436 & 10 & 4.044 & 545.072 & $* * *$ \\
\hline & Tides $*$ Stations & 0.713 & 30 & 0.024 & 3.203 & $* * *$ \\
\hline \multicolumn{7}{|l|}{$D O$} \\
\hline & Tides & 0.003 & 3 & 0.001 & 1.753 & NS \\
\hline & Stations & 0.778 & 10 & 0.078 & 162.592 & $* * *$ \\
\hline & Tides $*$ Stations & 0.118 & 30 & 0.004 & 8.208 & $* * *$ \\
\hline \multicolumn{7}{|c|}{ Temperature } \\
\hline & Tides & 0.096 & 3 & 0.032 & 233.992 & $* * *$ \\
\hline & Stations & 0.023 & 10 & 0.002 & 16.925 & $* * *$ \\
\hline & Tides * Stations & 0.026 & 30 & 0.001 & 6.400 & $* * *$ \\
\hline \multicolumn{7}{|c|}{ Chlorophyll a } \\
\hline & Tides & 0.051 & 3 & 0.017 & 63.602 & $* * *$ \\
\hline & Stations & 0.154 & 10 & 0.015 & 57.374 & $* * *$ \\
\hline & Tides * Stations & 0.069 & 30 & 0.002 & 8.519 & $* * *$ \\
\hline
\end{tabular}

Table 6: Tukey’s HSD post-hoc tests for comparing means of $\mathrm{pH}$, salinity, DO, temperature and chlorophyll $a$ concentration with different tides

\begin{tabular}{|c|c|c|c|c|c|c|}
\hline & & $\begin{array}{c}p H \\
p \text {-value }\end{array}$ & $\begin{array}{l}\text { Salinity } \\
\text { p-value }\end{array}$ & $\begin{array}{c}D O \\
\text { p-value }\end{array}$ & $\begin{array}{c}\text { Temperature } \\
\text { p-value }\end{array}$ & $\begin{array}{c}\text { Chla } \\
\text { p-value }\end{array}$ \\
\hline \multirow{3}{*}{ 1st_High Tide } & 1st_Low Tide & $* * *$ & NS & NS & $* * *$ & $* * *$ \\
\hline & 2nd_High Tide & $* * *$ & NS & NS & $* * *$ & $* * *$ \\
\hline & 2nd_Low Tide & $* * *$ & NS & $\mathrm{NS}$ & $* * *$ & $* * *$ \\
\hline \multirow{2}{*}{ 1st_Low Tide } & 2nd_High Tide & $* * *$ & NS & NS & $* * *$ & $* * *$ \\
\hline & 2nd_Low Tide & $* * *$ & NS & NS & NS & $* * *$ \\
\hline 2nd_High Tide & 2nd_Low Tide & $* * *$ & NS & NS & $* * *$ & $* * *$ \\
\hline
\end{tabular}


Table 7: Pearson Correlation coefficient, $r$, of the densities of different micro-phytoplankton with different physico-chemical parameters.

\begin{tabular}{lccccc}
\hline & Chlorophyll $\boldsymbol{a}$ & $\boldsymbol{p} \boldsymbol{H}$ & Salinity & DO & Temperature \\
\hline Diatom & $0.137^{*}$ & $0.066(\mathrm{NS})$ & $0.279^{* *}$ & $0.336^{* *}$ & $0.303^{* *}$ \\
\hline Dinoflagellates & $0.263^{* *}$ & $0.109(\mathrm{NS})$ & $0.317^{* *}$ & $0.181^{* *}$ & $0.336^{* *}$ \\
\hline Cyanobacteria & $0.036(\mathrm{NS})$ & $0.246^{* *}$ & $0.303^{* *}$ & $0.339^{* *}$ & $0.140^{*}$ \\
\hline $\boldsymbol{T P D}$ & $0.177^{* *}$ & $0.119(\mathrm{NS})$ & $0.339^{* *}$ & $0.345^{* *}$ & $0.344^{* *}$ \\
\hline & $\mathrm{p}<0.001=*^{* *}, \mathrm{p}<0.01=* *, \mathrm{p}<0.05=*, \mathrm{NS}=$ Not Significant &
\end{tabular}

\section{Discussion}

Tidal changes during a 24-hour cycle are very important, especially for organisms living in coastal waters, where it would bring fresh water, nutrients, oxygen and other inorganic matters (Gianesella et al., 2000). Moreover, in a closed barachois, where this study was conducted, the exchange of water was of utmost importance as there were limited passes for in-flow and outflow, and this would increase the residence time of the water in the barachois (Mudge et al., 2007).

During each 24-hour period, the diel variation of the micro-phytoplankton was observed. The density of micro-phytoplankton was significantly different throughout the four tidal changes (Frempong, 1981; Moser et al., 2012; 2017). Micro-phytoplankton, which were passively transported in coastal flows, needed light for photosynthesis to promote cellular growth and reproduction. The high densities of phytoplankton observed during the day tides $\left(2^{\text {nd }}\right.$ high and $2^{\text {nd }}$ low tides $)$ could be attributed to the availability of natural light penetrating through the waters. This eventually promoted a high productivity rate (Behrenfeld \& Falkowski, 1997). During the night, the productivity rate decreased drastically in the absence of natural light and, eventually, there was grazing of phytoplankton by zooplankton. It has been shown that zooplankton usually migrated to the upper layer of the water column at night to forage for food and escape predation (Shaw \& Robinson, 1998). The zooplankton grazing capacity and oyster consumption would determine the density of the phytoplankton population (Tian et al., 2016). The relationship between zooplankton and phytoplankton is inversely proportional (Goldyn \& Kowalczewska-Madura, 2007). Depending on size ratio, oysters have high filtration rate ranging from 1 to $4 \mathrm{~L} /$ hour of the water containing phytoplankton (Ehrich \& Harris, 2015).

Highest densities of phytoplankton are generally found in regions with low depths, muddy bottom and near mangroves (Kristensen et al., 2008). Together, these factors were characterized by low water flow rate. The highest density of cyanobacteria was also found in the same areas. Filamentous nitrogen-fixing cyanobacteria like Anabaena produce nitrates and nitrites at the bottom of the barachois (Kaneko, 2001; Casareto et al., 2008; Charpy et al., 2010). Eventually the changing of tides and increasing turbulence in the water column promoted the resuspension of benthic diatoms to the upper water column, together with a bottomup effect on the nutrients. The assimilation of nutrients for growth by the micro-phytoplankton might explain the high density of the latter in the muddy (high organic and inorganic content) regions adjacent to the mangrove ecosystem.

Throughout the study period, diatoms were found to be dominant, followed by dinoflagellates and cyanobacteria (Bernardi Aubry et al., 2006; Bazin et al., 2014). Diatoms have developed the ability to thrive in changing environments, even with temperature fluctuations or even limited light availability (Kokfelt et al., 2009). Among the dominant diatoms was Fragilaria, 
which was usually abundant near the freshwater ecosystem, which confirmed the interaction between the aquaculture system and river discharge nearby (Dauta et al., 1990). There was a high abundance of Nitzschia, but it was considered indigestible by the oyster compared to Chaetoceros, which was a good food source (Tomaru et al., 2002). Chaetoceros sp. was among the best food for oysters and could promote a growth rup to a ate of $2.21 \mathrm{~g} /$ month (McCausland et al., 1999; Hashimoto et al., 2008). Other dominant diatoms found were Coscinodiscus, Navicula and Licmorphora (Kasim \& Mukai, 2006; Carstensen et al., 2015).

There was no significant variation in salinity during tidal changes. This may be attributed to the effect of a partially-closed aquaculture system. Salinity was identified as a strong factor affecting phytoplankton community structure (Larson \& Belovsky, 2013). The level of DO did not vary significantly. This may imply that there was a low water exchange rate between the aquaculture farm and adjacent waters. The fairly unchanged level of DO was indicative of the proper functioning of the marine ecosystem as consumed oxygen was being replaced to maintain equilibrium. There was a positive correlation between $\mathrm{DO}$ and $\mathrm{pH}$ during the experiment at all stations, where the $\mathrm{pH}$ values were above 8 , which implied that the area was well oxygenated and there was no accumulation of carbon dioxide $\left(\mathrm{CO}_{2}\right)$, which meant that there was a low respiration rate compared to its production rate.

It has been reported that the level of DO in seawater increases during strong winds (Ridder \& England, 2014) because of turbulence, which causes the oxygenation of water (Yamamoto et al., 2015). The strong significant variation in temperature during the tidal change could be attributed to insolation whereby the $2^{\text {nd }} \mathrm{HT}$ and 2nd LT occurred during daytime. There was no cloud coverage during daytime sampling and thus, insolation was maximum, and the highest temperature recorded was during the $2^{\text {nd }} \mathrm{HT}$ and 2nd LT (Dunstan et al., 2018). The significant change in $\mathrm{pH}$ at different tides could be due to a change in the photosynthetic rate of microalgae in the water. The DO level was supersaturated, coupled with a relatively high $\mathrm{pH}$, and this could promote the growth and reproduction of phytoplankton. The high DO could provide the right conditions to attain optimal oyster growth rate as DO had been shown to be a critical determinant in the health and stress conditions of oysters ( Stickle et al., 1989; Baker \& Mann, 1994).

\section{Conclusion}

This study reported the variations in microphytoplankton density and diversity throughout two 24-hour cycle period over two diel cycles, together with associated parameters like chlorophyll $a$ concentration, $\mathrm{pH}$, salinity, DO and sea surface temperature. The physicochemical parameters studied give us an insight on the status of the water quality throughout the different tidal changes. Moreover, the high $\mathrm{pH}$ variation could be used to predict if the system was functioning properly, whereby we could probably assume that the micro-phytoplankton were uptaking enough carbon diocide to perform photosynthesis, which helped in maintaining the $\mathrm{pH}$ of the water at an optimum level. The highest densities of micro-phytoplankton were found at S3 and S6. Diversity indices performed at both stations were comparable. It implied that in addition to S6, S3 was another area where oyster culturing could be practiced with respect to sufficient micro-phytoplankton availability. Owing to the global rise in sea temperature, many small oyster entrepreneurs were reporting cases of mass mortality of their molluscs. One probable solution was to increase the production rate to minimize losses caused by the high mortality rate. Hence, exploring S3 as a potential area to produce more oysters could help move towards a higher optimization of the barachois.

\section{Acknowledgements}

The authors would like to thank the Mauritian Ministry of Blue Economy, Marine Resources, Fisheries and Shipping for granting permits for 
sample collection, the University of Mauritius for the its laboratory facilities and Persand Khemraj for allowing access to his aquaculture farm. The authors are also grateful to the Western Indian Ocean Marine Science Association (WIOMSA) for providing a travel grant under the MARG-III scheme.

\section{References}

Armance, M., Mattan-Moorgawa, S., \& Bhagooli, R. (2019). Micro-phytoplankton density and diversity at a pilot oyster culture barachois site of Mauritius Island. Ocean Life, 3(1), 1-12.

Baker, S., \& Mann, R. (1994). Description of metamorphic phases in the oyster Crassostrea virginica and effects of hypoxia on metamorphosis. Marine Ecology Progress Series, 104, 91-99. https://doi. org/10.3354/meps 104091

Bates, S. S., Freitas, A. S. W. de., Milley, J. E., Pocklington, R., Quilliam, M. A., Smith, J. C., \& Worms, J. (1991). Controls on domoic acid production by the diatom Nitzschia pungens f. multiseries in culture: Nutrients and irradïance. Journal Fisheries Aquatic Science, 48(7), 1136-1144. https:// doi.org/10.1139/f91-137

Bazin, P., Jouenne, F., Friedl, T., DetonCabanillas, A. -F., Le Roy, B., \& Véron, B. (2014). Phytoplankton diversity and community composition along the estuarine gradient of a temperate macrotidal ecosystem: Combined morphological and molecular approaches. PLoS ONE, 9(4), e94110. https://doi.org/10.1371/journal. pone. 0094110

Behrenfeld, M. J., \& Falkowski, P. G. (1997). A consumer's guide to phytoplankton primary productivity models. Limnology and Oceanography, 42(7), 1479-1491.

Bernard, I., de Kermoysan, G., \& Pouvreau, S. (2011). Effect of phytoplankton and temperature on the reproduction of the Pacific oyster Crassostrea gigas:
Investigation through DEB theory. Journal of Sea Research, 66(4), 349-360.

Bernardi Aubry, F., Acri, F., Bastianini, M., Bianchi, F., Cassin, D., Pugnetti, A., \& Socal, G., 2006. Seasonal and interannual variations of phytoplankton in the Gulf of Venice (Northern Adriatic Sea). Chemistry and Ecology, 22(1), S71-S91.

Bhagooli, R., \& Hidaka, M. (2004). Release of zooxanthellae with intact photosynthetic activity by the coral Galaxea fascicularis in response to high temperature stress. Marine Biology, 145, 329-337. https://doi. org/10.1007/s00227-004-1309-7

Bhagooli, R., \& Kaullysing, D. (2019). Seas of Mauritius, 2nd ed. Sheppard. 253-277. http://10.1016/B97-0-08-100853-9.00016-6

Bhagooli, R., \& Sheppard, C. (2012). Prediction of recurrences of mass coral bleaching / mortality and vulnerability of reef-building corals to climate change in Mauritian and Japanese waters, pp. 105-1211.

Bhagooli, R., \& Taleb-Hossenkhan, N. (2012). Thermal spatial heterogeneity and coral bleaching: implications for habitat refuges. (Conference Paper: International Coral Reef Symposium 2012, Cairns, Australia)

Browman, H., \& Stergiou, K. (Eds.), (2004). Perspectives on ecosystem-based approaches to the management of marine resources. Marine Ecology Progress Series, 274, 269-303.

Brown, J. R., \& Hartwick, E. B. (1988). Influences of Temperature, Salinity and Available Food Upon Suspended Culture of the Pacific Oyster, Crussostrea gigas I. Aquaculture, 20(3), 231-251.

Carstensen, J., Klais, R., \& Cloern, J. E. (2015). Phytoplankton blooms in estuarine and coastal waters: Seasonal patterns and key species. Estuarine, Coastal and Shelf Science, 162, 98-109. https://doi. org/10.1016/j.ecss.2015.05.005

Casareto, B. E., Charpy, L., Langlade, M. J., Suzuki, T., Ohba, H., Niraula, M., \& 
Suzuki, Y., (2008). Nitrogen fixation in coral reef environments. Proceedings of the 11th International Coral Reef Symposium, Ft. Lauderdale, Florida.

Cembella, A. D., Lewis, N. I., \& Quilliam, M. A. (2000). The marine dinoflagellate Alexandrium ostenfeldii (Dinophyceae) as the causative organism of spirolide shellfish toxins. Phycologia, 39, 67-74. https://doi. org/10.2216/i0031-8884-39-1-67.1

Charpy, L., Palinska, K. A., Casareto, B., Langlade, M. J., Suzuki, Y., Abed, R. M. M., \& Golubic, S. (2010). Dinitrogenfixing cyanobacteria in microbial mats of two shallow coral reef ecosystems. Microbial Ecololgy, 59, 174-186. https:// doi.org/10.1007/s00248-009-9576-y

Coleman, F. C., \& Williams, S. L. (2002). Overexploiting marine ecosystem engineers: potential consequences for biodiversity. Trends in Ecology \& Evolution, 17, 40-44.

Dauta, A., Devaux, J., Piquemal, F., \& Boumnich, L. (1990). Growth rate of four freshwater algae in relation to light and temperature. Hydrobiologia, 207, 221-226.

de Kantzow, M., Hick, P., Becker, J., \& Whittington, R. (2016). Effect of water temperature on mortality of Pacific oysters Crassostrea gigas associated with microvariant ostreid herpesvirus 1 (OsHV-1 $\mu$ Var). Aquaculture Environment Interaction, 8, 419-428.

Devassy, V. P., \& Goes, J. I. (1991). Phytoplankton assemblages and pigments in the exclusive economic zone of Mauritius (Indian Ocean). Indian Journal of Marine Sciences, 20, 163-168

Dunstan, P. K., Foster, S. D., King, E., Risbey, J., O'Kane, T. J., Monselesan, D., Hobday, A. J., Hartog, J. R., \& Thompson, P. A. (2018). Global patterns of change and variation in sea surface temperature and chlorophyll a. Scientific Report, 8, 14624. https://doi. org/10.1038/s41598-018-33057-y
Ehrich, M. K., \& Harris, L. A. (2015). A review of existing eastern oyster filtration rate models. Ecological Modelling, 297: 201-212. https://doi.org/10.1016/j. ecolmodel.2014.11.023

Frempong, E. (1981). Diel variation in the abundance, vertical distribution, and species composition of phytoplankton in a Eutrophic English Lake. The Journal of Ecology, 69: 919. https://doi.org/10.2307/2259645

Gagnaire, B., Frouin, H., Moreau, K., ThomasGuyon, H., \& Renault, T. (2006). Effects of temperature and salinity on haemocyte activities of the Pacific oyster, Crassostrea gigas (Thunberg). Fish \& Shellfish Immunology, 20: 536-547.

Gianesella, S. M. F., Saldanha-CorreÃa, F. M. P., \& Teixeira, C. (2000). Tidal effects on nutrients and phytoplankton distribution in Bertioga Channel, SaÄo Paulo, Brazil. Aquatic Ecosystem Health and Management, 3(4), 533-544.

Goldyn, R., \& Kowalczewska-Madura, K. (2007). Interactions between phytoplankton and zooplankton in the hypertrophic Swarzedzkie Lake in western Poland. Journal of Plankton Research, 30, 33-42. https://doi.org/10.1093/plankt/fbm086

Hashimoto, T., Hyodoh, K., Hirose, T., Nishikawa, S., Katano, T., \& Nakano, S. (2008). Evaluation of three phytoplankton species as food for the pearl oyster Pinctada fucata. Aquaculture International, 16, 309318. https://doi.org/10.1007/s10499-0079144-8

Jeffrey, S. W., \& Humphrey, G. F. (1975). New spectrophotometric equations for determining chlorophylls a, b, c1 and c2 in higher plants, algae and natural phytoplankton. Biochemie und Physiologie der Pflanzen, 167, 191-194.

Jiang, Tao., Liu, L., Li, Y., Zhang, J., Tan, Z., Wu, H., Jiang, Tianjiu., \& Lu, S. (2017). Occurrence of marine algal toxins in oyster and phytoplankton samples in Daya Bay, South China Sea. Chemosphere, 
183, 80-88. https://doi.org/10.1016/j. chemosphere.2017.05.067

Jiang, W., \& Gibbs, M. T. (2005). Predicting the carrying capacity of bivalve shellfish culture using a steady, linear food web model. Aquaculture, 244, 171-185.

Kaneko, T. (2001). Complete Genomic Sequence of the Filamentous Nitrogenfixing Cyanobacterium Anabaena sp. Strain PCC 7120. DNA Research, 8, 205-213.

Kasim, M., \& Mukai, H. (2006). Contribution of benthic and epiphytic diatoms to calm and oyster production in the Akkeshi-ko estuary. Journal Oceanography, 62, 267-281.

Kokfelt, U., Struyf, E., \& Randsalu, L. (2009). Diatoms in peat - Dominant producers in a changing environment? Soil Biology and Biochemistry, 41, 1764-1766.

Kristensen, E., Bouillon, S., Dittmar, T., \& Marchand, C. (2008). Organic carbon dynamics in mangrove ecosystems: A review. Aquatic Botany, 89, 201-219.

Larson, C. A., \& Belovsky, G. E. (2013). Salinity and nutrients influence species richness and evenness of phytoplankton communities in microcosm experiments from Great Salt Lake, Utah, USA. Journal of Plankton Research, 35, 1154-1166.

Lauck, T., Clark, C. W., Mangel, M., \& Munro, G. R. (1998). Implementing the precautionary principle in fisheries management through marine reserves. Ecological Applications, 8, S72-S78.

McCausland, M. A., Brown, M. R., Barrett, S. M., Diemar, J. A., \& Heasman, M. P. (1999). Evaluation of live microalgae and microalgal pastes as supplementary food for juvenile pacific oysters. Aquaculture, 174(3-4), 323-342.

Moser, G., Ciotti, A., Giannini, M., Tonini, R., \& Harari, J. (2012). Changes in phytoplankton composition in response to tides, windinduced mixing conditions, and freshwater outflows in an urbanised estuarine complex. Brazilian Journal Biology, 72, 97-111.
Moser, G. A. O., Piedras, F. R., Oaquim, A. B .J., Souza, D. S., Leles, S. G., de Lima, D. T., Ramos, A. B. A., Farias, C. de O., \& Fernandes, A. M. (2017). Tidal effects on phytoplankton assemblages in a nearpristine estuary: a trait-based approach for the case of a shallow tropical ecosystem in Brazil. Marine Ecology, 38, e12450.

Mudge, S. M., Icely, J. D., \& Newton, A. (2007). Oxygen depletion in relation to water residence times. Journal Environment Monitoring, 9, 1194-1198. https://doi. org/10.1039/b708178b

Ridder, N. N., \& England, M. H. (2014). Sensitivity of ocean oxygenation to variations in tropical zonal wind stress magnitude. Global Biogeochemical Cycles, 28, 909-926.

Sadally, S., Taleb-Hossenkhan, N., \& Bhagooli, R. (2014a). Spatio-temporal variation in density of microphytoplankton genera in two tropical coral reefs of Mauritius. African Journal of Marine Science, 36, 423-438. https://doi.org/10.2989/181423 2X.2014.973445

Sadally, S. B., Nazurally, N., Taleb-Hossenkhan, N., \& Bhagooli, R. (2014b). Microphytoplankton distribution and biomass in and around a channel-based fish farm: implications for sustainable aquaculture. Acta Oceanologica Sinica, 33: 180-191.

Sadally, S. B., Taleb-Hossenkhan, N., Casareto, B., Suzuki, Y., \& Bhagooli, R. (2015). Micro-tidal dependent microphytoplankton C-biomass dynamics of two shallow tropical coral reefs 22 . WIO Journal of Marine Science, 22, 53-72.

Shaw, W., \& Robinson, C. (1998). Night versus day abundance estimates of zooplankton at two coastal stations in British Columbia, Canada. Marine Ecology Progress Series, 175,143-153. https://doi.org/10.3354/meps 175143

Stickle, W. B., Kapper, M. A., Liu, L. -L., Gnaiger, E., \& Wang, S. Y. (1989). Metabolic Adaptations of Several Species 
of Crustaceans and Molluscs to Hypoxia: Tolerance and Microcalorimetric Studies. The Biological Bulletin, 177, 303-312.

Tangen, K. (1983). Shellfish poisoning and the ocurrence of potentially toxic dinoflagellates in Norwegian waters. Sarsia, 68: 1-7. https://doi.org/10.1080/00364827.1983.10 420550

Tian, W., Zhang, H., Zhao, L., Xu, X., \& Huang, H. (2016). The Relationship between Phytoplankton Evenness and Copepod Abundance in Lake Nansihu, China. International Journal of Environmental Research and Public Health, 13, 855. https://doi.org/10.3390/ijerph13090855.

Tomaru, Y., Udaka, N., Kawabata, Z., \& Nakano, S. (2002). Seasonal change of seston size distribution and phytoplankton composition in bivalve pearl oyster Pinctada fucata martensii culture farm. Hydrobiologia, 481, 185-188.

Tomas, C. R. (1996). Identifying Marine Diatoms and Dinoflagellates. Academic Press, San Diego.

Turner, J., Hardman, E., Klaus, R., Fagoonee, I., Daby, D., \& Baghooli, R. (2002). The reefs of Mauritius 11.

Yamamoto, A., Abe-Ouchi, A., Shigemitsu, M., Oka, A., Takahashi, K., Ohgaito, R., \& Yamanaka, Y. (2015). Global deep ocean oxygenation by enhanced ventilation in the Southern Ocean under long-term global warming: Oxygenation under global warming. Global Biogeochemical Cycles, 29, 1801-1815. https://doi. org/10.1002/2015GB005181 